\title{
Diffusion of Solar Energy Use in the Built Environment Supported by New Design
}

\author{
Marina van Geenhuizen ${ }^{1}$, Joop Schoonman ${ }^{2}$ and Angèle Reinders ${ }^{3,4}$ \\ 1. Faculty of Technology, Policy and Management, Delft University of Technology, Delft 2628 CE, The Netherlands \\ 2. Faculty of Applied Sciences, Delft University of Technology, Delft 2628 CE, The Netherlands \\ 3. Faculty of Engineering Technology, Univiversity of Twente, Enschede 7500 AR, The Netherlands \\ 4. Faculty of Industrial Design Engineering, Delft University of Technology, Delft 2628 CE, The Netherlands
}

\begin{abstract}
Places of large potentials of sustainable energy production and places of large energy consumption are often very different and separated by large distances across the globe. This paper first discusses potentials of solar technology in terms of global availability using PV (photovoltaic) technology and actual energy production. Solar energy is widely under-used and one way to reduce this is to improve production in low-energy places with high demand: large cities. According to this option, about $40 \%$ of the electricity consumption in the built environment could be produced by solar PV systems and energy storage systems. This paper discusses conditions in the built environment and functional and design qualities enabling an increased diffusion of the technologies. In a comparative analysis of PV technologies, the criteria taken into account encompass efficiency of the type of solar cell and commercial availability. Special attention is paid to the design features of different PV systems, like flexibility, colour and transparency that might help in their utilization as integrated in building material and ornaments in modern architecture. The same procedure is followed for electricity storage devices. The preliminary conclusion is that at present the freedom of design is largest for a combination of crystalline silicon PV cells and Li-ion batteries.
\end{abstract}

Key words: Solar PV energy systems, battery storage systems, design qualities, built environment.

\section{Introduction}

There are many reasons for considering an increased use of renewable energy sources that can supplement or perhaps even replace part of the conventional fossil fuel-based energy production types that are most prevalent today [1]. First is the future security of supply. It is not clear how long we can be sure of deliveries of coal, oil and natural gas at affordable prices. An undisrupted energy supply is needed for a growing population and economy, particularly as fossil fuels become more costly and harder to find and extract. Secondly, environmental considerations are a reason to choose alternative sources of energy. In general, the scientific community involved in investigating climate change,

Corresponding author: Angèle Reinders, Dr., Prof., research fields: sustainable design, photovoltaics and smart grids. E-mail: a.h.m.e.reinders@utwente.nl. agrees that burning fossil fuels contributes to global warming that enhances melting of glaciers and rising of the sea levels. Global warming is also expected to increase severity of tropical storms, to shift the location of viable agriculture, to harm ecosystems and animal habitats, and to change the timing and magnitude of water supply. A third reason to focus on renewable energy technologies is the employment and export possibilities, which emerge in connection with research and development in the field [2].

To date a large part of the population in the world lives in cities and, if current trends continue, two-thirds of the world's population will be urbanized by 2050 [3]. This means that cities will be the largest energy consumers and contributors to greenhouse gasses. Currently, about $75 \%$ of energy is consumed in large cities [4-7]. Cities are thus an important frame to 
connect solar PV (photovoltaic) technology ${ }^{1}$ with the built environment. In addition, there is growing consensus that distributed solar PV systems providing electricity at the point of use, will be the first to reach widespread commercialization. Chief among these distributed applications are systems for individual buildings [8].

Solar PV systems produce energy without noise and emissions, in a safe manner and only with small maintenance needs, and it seems likely that solar PV systems become integrated in buildings in roofs, facades, windows etc. and start even to perform as building material. Commercialization may be particularly enhanced based upon design qualities in the context of modern architecture, like flexibility to allow use in curved facades, being colored or allowing a change of color, and performance as distributed system of clusters of PV cells as ornaments, also inhibiting certain aesthetical qualities. Indeed, the IEA (International Energy Agency) technological roadmap says: Solar photovoltaic energy presents the short-term, mid-term and long-term research and development priorities for PV [9]. Among these short-term and mid-term R\&D priorities are: Design solar PV as a building material and architectural element that meets the technical, functional and aesthetical requirements, along with cost targets. To reach such goals, we need appropriate solar PV energy conversion devices and also battery storage systems, the latter because of the variation in solar radiation and in energy consumption [10].

The question addressed in this paper is the optimal combination of solar PV systems and battery storage systems. The paper discusses important conditions in the built environment and various functional and design qualities that enable an increased application of the technologies. In an assessment, the same analysis is

${ }^{1}$ Photovoltaic systems use cells to convert solar radiation into electricity. The cell usually consists of two layers of a semi-conducting material. When light shines on the cell, it creates an electric field across the layers, causing electricity to flow. followed for PV technology and battery storage devices. The paper is structured as follows: First, solar PV technology is reviewed with regard to availability of the source, progress in research to combat disadvantages of the technology and various economic characteristics (Section 2); Next, attention moves to a comparative analysis of solar PV systems from the viewpoint of the built environment and architecture (Section 3); This is followed by a similar type of analysis of storage systems using batteries (Section 4); The last section concludes on the most promising systems.

\section{Solar PVs (Photovoltaics)}

What is unique for solar cell technology, is that it can be used highly functional in a modular way from small power applications of several milliWatts for instance in solar powered watches, to very large scale, PV systems of tenths of MegaWatts, also known as solar farms [11]. Because of their modular characteristics PV systems can be easily applied in modern architecture of buildings.

Solar energy is widely available across the world and in much larger amounts than wind energy, for instance, according to energy studies executed by Greenpeace (2007, 2008, 2010 and 2012) [12], the resource availability of solar irradiation is globally a factor 15 higher than the resource availability of wind energy excluding technical conversions of this energy into electricity. About 14,900 $\mathrm{PWh} \cdot \mathrm{yr}^{-1}$ are theoretically available over land for PV systems (Table 1) [13]. The capture of even $1 \%$ of this power would supply more than the world's power needs. However, there are considerable differences in intensity of radiation (direct and diffuse light). Within Europe, for example, the difference in yearly average is a factor 1-2 from northern to southern Europe and, more important, the seasonal variation (summer-winter) in the north is 1-10 compared to 1-4 in the south [10]. An estimation of solar PV power worldwide, assuming the use of $160 \mathrm{~W}$ solar panels, indicates overall higher scores compared 
to wind energy $(6,500 \mathrm{TW}$ versus $1,700 \mathrm{TW})$ [14] (Table 1). The same holds for power generated in high-energy locations (1,300 TW versus 72-170 TW).

If we take into account current power delivered as electricity, however, the situation is reversed $(0.0013$ versus $0.02 \mathrm{TW}$ ), meaning that a large amount of solar energy is not used. On the availability side, this situation is related to variability in radiation and to availability of solar energy mainly in those places (high-energy locations) where there is virtually no local demand for electricity. Responses to this situation are twofold, that is: (1) solar power could be produced in high-energy locations and then transferred to places of high demand; and (2) solar power could be profitably produced in low-energy locations with high demand, namely in cities in the built environment. This paper is concerned with the last, with special attention for solar PV devices as building material, including ones serving aesthetic goals.

Solar PV systems are arrays of solar cells containing materials that convert solar radiation into DC (direct-current) electricity. Materials used today include various types of silicon, polymers and new nano-structured materials. A silicon-based solar cell comprises a combination of a thin film of n-type silicon and a thin film of p-type silicon. In general, PV performance is limited when the cell temperature exceeds a threshold, but this varies with the material used. PVs can be mounted on roofs or combined into solar-PV farms. Such farms today may range from 10 to $60 \mathrm{MW}$ and in the near future to $150 \mathrm{MW}$ [6]. Most capacity of PV modules is on rooftops, meaning that in historical cities PV modules may reduce aesthetic value of the buildings. However, solar cells are expected to be increasingly integrated in parts of buildings, like windows and walls, which can be applied in newly constructed buildings, but also in renovated buildings. The energy payback time for silicon-based solar cells is estimated to be relatively long, i.e., three to four years, depending on the type of used silicon (e.g., SEC [15]).

Obstacles to adoption mainly refer to a combination of relatively low efficiency of silicon-based solar cells and relatively high price of silicon-based systems compared to alternative energy sources. Typical conversion efficiencies for silicon-based PV modules are in the range of $5 \%$ to $15 \%$, depending on the type. Important improvements are expected, among others based on a new production process of amorphous silicon thin-film solar cells on a flexible substrate deposited in a roll-to-roll process, producing a substantial decrease of use of silicon and hence cheaper materials costs.

Other types of solar cells, which are substantially cheaper, include the Grätzel cell [16], which mimics the natural photosynthesis by using a dye-sensitized nano-structured semi-conductor based solar cell. The Grätzel cell comprises a thin film of n-type nano-porous anatase-structured titanium dioxide, $\mathrm{TiO}_{2}$, covered with a monolayer of a ruthenium-based visible-light absorbing dye molecule. This photo-electrode is immersed in a liquid electrolyte, acetonitrile, containing an iodide/iodine redox couple and a counter electrode. The conversion efficiency of the commercial Grätzel cell is about $9 \%$, but the use of a combination of two different visible-light absorbing dye molecules will increase the conversion efficiency substantially (by $25 \%$ ).

Table 1 Solar PV globally available energy, power in different locations and installed power (electricity) (wind energy as reference).

\begin{tabular}{lllll}
\hline Technology & Available energy/PWh.yr ${ }^{-1}$ & Power worldwide (TW) & $\begin{array}{l}\text { Power in high-energy } \\
\text { locations (TW) }\end{array}$ & Delivered as electricity (TW) \\
\hline Solar PV & 14,900 & $6,500^{\mathrm{a}}$ & $1,300^{\mathrm{c}}$ & 0.0013 \\
Wind & 630 & $1,700^{\mathrm{b}}$ & $72-170$ & 0.02 \\
\hline
\end{tabular}

Adapted from Jacobson [13] and Jacobson and Delucchi [14]. ${ }^{\mathrm{a}}$ Assuming the use of $160 \mathrm{~W}$ solar panels and areas over all latitudes, land and ocean; ${ }^{b}$ accounts for all wind speeds at 100 meter over land and ocean; ${ }^{c}$ same as ${ }^{a}$, but locations between latitudes $50 \mathrm{~S}$ and $50 \mathrm{~N}$. 
Different from the above mentioned silicon-based solar cells, the energy payback time of the Grätzel cell is less than one year. Other major improvements on the cost-side are solar cells based on new nano-structured composite materials, e.g., titanium dioxide, copper indium disulfide and copper indium gallium diselenide, which are cheap and face a relatively short energy payback time. However, these new types of cells do not exhibit an improved efficiency (around 7\%). A next generation solar cell shall be based on the use of quantum dots and an estimated theoretical efficiency of about $82 \%$, which means a substantial increase compared with current generations, but research has just taken off.

Of course, solar cells produce energy only during the day. In the case of solar panels on houses, this means that the system needs to be connected to the electricity grid. During night, electricity can be drawn from the grid, whereas in daytime a surplus of solar energy (compared to its use) can be delivered to the grid. At this point, agreements with electricity producers come in, particularly regarding the price of the solar energy delivered to the grid. Another solution would be to store surplus of solar energy in batteries. We will limit our attention to this second option.

\section{Solar PV Technology and Design in the Built Environment}

In this section, we focus on the following five PV technologies: single crystalline $(\mathrm{x}-\mathrm{Si})$ and poly-crystalline solar cells ( $\mathrm{p}-\mathrm{Si}$ ); amorphous silicon-based solar cells (a-Si); dye-sensitized solar cells, i.e., the Grätzel Cell, abbreviated as DSSC; cadmium telluride, CdTe; and copper-indium-gallium-diselenide solar cells (CIGS). We investigate the opportunities to create different types of designs with these PV technologies, in particular with a focus on use of products in the built environment. Solar PV systems in this context are compared particularly regarding their potentials as an aesthetic building material and "shaper" in modern architecture or as ornaments. We explore these opportunities in three directions: (1) two-dimensional design; (2) three-dimensional design; (3) coloring and transparency (Table 2).

In our scope, two-dimensional design refers to: (a) patterning, (b) shaping of edges, for instance for an ellipsoid PV roof. For three-dimensional design, we distinguish between the following two points; (c) curvature of surfaces, like the PV elements of a so-called PV bubble module; (d) spatially distributed structures like 500 butterfly-shaped silicon solar cells. The two features color and transparency represent respectively the visually perceived color of the PV laminate and the share of light which can pass through the PV module.

Looking at the use of PV technology in the built environment, all mentioned elements in our table should be optimally customizable, i.e., sizing, patterning, shaping of edges, bending and curvature, coloring and transparency. By changing these features different types of PV modules can be created with various appearances and various applications, for instance roofing elements, facades, window-integrated elements and sky lights.

After a comparison of the features of PV technologies, we draw that conclusion that out of the five technologies the silicon-based PV cells and the DSSC (dye-sensitized solar cells) provide the best opportunities. At present, the life time of the DSSC, while commercially available, is too short to compete with the silicon-based solar cells. The different colors of the sc-Si and pc-Si solar cells are due to differences in the layer thickness of the anti-reflection coating. In the usually blue-colored solar cells the thickness of the anti-reflection coating is optimized for energy production.

Recent developments in the field of OPV (organic polymer PV solar cells) suggest a potential for applications in the built environment which might come close to silicon PV solar cells, however at present, the efficiency and life time of OPV are far beyond 
Table 2 Design features of PV technologies.

\begin{tabular}{|c|c|c|c|c|c|c|}
\hline $\begin{array}{l}\text { PV tech- } \\
\text { nologies }\end{array}$ & $\begin{array}{l}\text { Typical size } \\
\text { Substrate (mm } \\
\times \text { mm) }\end{array}$ & Patterning & $\begin{array}{l}\text { Shaping of } \\
\text { edges }\end{array}$ & Bending andcurvature & Color & Transparency \\
\hline CdTe & $\begin{array}{l}\text { Customizable } \\
\text { from } 10 \times 10 \text { to } \\
1,000 \times 2,000, \\
\text { rigid and } \\
\text { flexible }\end{array}$ & $\begin{array}{l}\text { Scen printing } \\
\text { front glass }\end{array}$ & n.a. & Flex & $\begin{array}{l}\text { Cells are brownish or } \\
\text { black. Color by colored } \\
\text { front glass }\end{array}$ & $\begin{array}{l}\text { Semi-transparency } \\
\text { by wider space } \\
\text { between cells and } \\
\text { laser scribing }\end{array}$ \\
\hline CIGS & $\begin{array}{l}\text { Customizable } \\
\text { from } 10 \times 10 \text { to } \\
1,000 \times 2,000, \\
\text { rigid and } \\
\text { flexible }\end{array}$ & $\begin{array}{l}\text { Screen printing } \\
\text { front glass }\end{array}$ & n.a. & Flexibl & Colored front glass & $\begin{array}{l}\text { Semi-transparency } \\
\text { by wider space } \\
\text { between cells and } \\
\text { laser scribing }\end{array}$ \\
\hline $\mathrm{a}-\mathrm{Si}$ & $\begin{array}{l}\text { Customizable } \\
\text { from } 10 \times 10 \text { to } \\
1,000 \times 2,000, \\
\text { rigid and } \\
\text { flexible }\end{array}$ & $\begin{array}{l}\text { Screen printing } \\
\text { front glass }\end{array}$ & n.a. & Flexible substrate & $\begin{array}{l}\text { Cells are usually } \\
\text { brownish or black, } \\
\text { other colors can be } \\
\text { produced }\end{array}$ & $\begin{array}{l}\text { Semi-transparency } \\
\text { by wider space } \\
\text { between cells and } \\
\text { laser scribing }\end{array}$ \\
\hline${ }_{\mathrm{x}-\mathrm{Si} / \mathrm{p}-\mathrm{Si}}$ & $\begin{array}{l}156 \times 156 \\
\text { (cells), } \\
\text { rigid only due } \\
\text { to the fragility } \\
\text { of the cells }\end{array}$ & 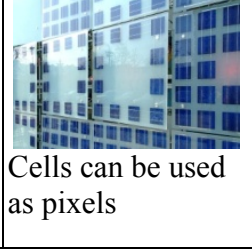 & Laser cutting & $\frac{1}{\begin{array}{l}\text { Curvature by rigid carrier } \\
\text { substrate }\end{array}}$ & $\begin{array}{l}\text { Pells are usually blue, } \\
\begin{array}{l}\text { Cells ather colors can be } \\
\text { produced }\end{array}\end{array}$ & $\begin{array}{l}\text { Semi-transparency } \\
\text { by wider space } \\
\text { between cells and } \\
\text { punching holes in } \\
\text { cells }\end{array}$ \\
\hline DSSC & $\begin{array}{l}\text { Customizable } \\
\text { from } 10 \times 10 \text { to } \\
1,000 \times 2,000, \\
\text { rigid and } \\
\text { flexible }\end{array}$ & $\begin{array}{l}\text { Cells can be used } \\
\text { as pixels }\end{array}$ & $\begin{array}{l}\text { Defined by } \\
\text { cell geometry, } \\
\text { i.e., shaping } \\
\text { of cell }\end{array}$ & Flexible substrate & $\begin{array}{l}\text { Orange, reddish, purple, } \\
\text { depending on the dye } \\
\text { applied }\end{array}$ & Always transparent \\
\hline
\end{tabular}

acceptable levels for applications in building envelopes.

\section{Battery Storage Systems and Design in the Built Environment}

In this study, we will focus on storage using rechargeable batteries, their practical specifications and design potentials. To date, several rechargeable battery systems are available. They are based on the following electro-chemistries, i.e., Lead-acid (Pb-acid), Nickel-Cadmium (Ni-Cd), Nickel-Metal Hydride (Ni-MH), lithium (Li) and lithium-ion $\left(\mathrm{Li}^{+}\right)$, and the zinc-air, or lithium-air battery. The Ni-Cd battery is nowadays replaced by the Ni-MH battery, because cadmium is no longer accepted in the environment.

Batteries store chemical energy and convert it into electrical energy, e.g., $\mathrm{Pb}$-acid batteries to start car engines. With slightly modified electrodes $\mathrm{Pb}$-acid batteries are used for the decentralized storage of photovoltaic electrical energy. The nominal cell voltage, the specific energy, the energy density, the cycle life, and the efficiency of selected batteries are presented in Table 3.

The specific energy of the $\mathrm{Pb}$-acid battery is small compared to the other battery types, because of its heavy weight. This would imply that for large-scale storage of photovoltaic electrical energy the required 
Table 3 Practical specifications of selected battery types [17].

\begin{tabular}{llllll}
\hline Battery type & $\begin{array}{l}\text { Nominal cell } \\
\text { voltage (V) }\end{array}$ & $\begin{array}{l}\text { Specific energy } \\
(\mathrm{Wh} / \mathrm{kg})\end{array}$ & $\begin{array}{l}\text { Energy density } \\
(\mathrm{Wh} / \mathrm{L})\end{array}$ & $\begin{array}{l}\text { Cycle life, 20\% } \\
\text { fading (cycles) }\end{array}$ & Efficiency (\%) \\
\hline Sulphuric lead-acid & 2.0 & $30-50$ & $80-90$ & $200-500$ & 85 \\
Nickel metal hydride & 1.2 & $75-120$ & 240 & $300-500$ & \\
Lithium-ion & 4.1 & $110-160$ & $400-500$ & $500-1,000$ & $95-98$ \\
Lithium/manganese dioxide & 3.0 & $100-135$ & $265-350$ & $300-500 / 2,000$ & \\
\hline
\end{tabular}

battery package would be very heavy. Since solar radiance is usually abundantly available on top of buildings or on facades which usually have both a structural function in buildings, a low energy density and hence a high weight of batteries would not be very favorable for integrated designs of PV elements with $\mathrm{Pb}$-acid batteries.

Since lithium is the lightest element on earth, lithium batteries have a very high specific capacity. Moreover, lithium has the lowest electrochemical potential, i.e., $\mathrm{E}^{\mathrm{O}}\left(\mathrm{Li}^{+} / \mathrm{Li}\right)=-0.3045 \mathrm{~V} / \mathrm{NHE}$ (NHE - normal hydrogen electrode as reference) and, therefore, the output potential is also high, as can be seen in Table 3. The great performances of lithium-ion batteries are based on the use of lithium ions, $\mathrm{Li}^{+}$, which are shuttled between the positive and the negative electrode through the electrolyte. At present, the lithium batteries attract widespread attention, because they almost fulfill the requirements for (hybrid) electrical vehicles, as the lithium battery technology is superior in terms of power and energy density, achieved by a combination of a large specific capacity, current and a high output potential.

In addition, this is supported by a comparison of the gravimetric and volumetric energy densities of the various rechargeable battery systems, presented in
Fig. 1.

The $\mathrm{Pb}$-acid, the Ni-MH, the lithium-ion $\left(\mathrm{Li}^{+}\right)$and the lithium-manganese dioxide have different designs [18] and the design aspects of these batteries are presented in Table 4.

With regard to lithium-ion rechargeable batteries, product opportunities by novel designs have recently attracted attention. The novel designs are especially related to the shape ability of the battery to make it fit for dedicated product applications, like for instance very thin batteries for integration at the back of a PV module, or curved batteries and transparent battery

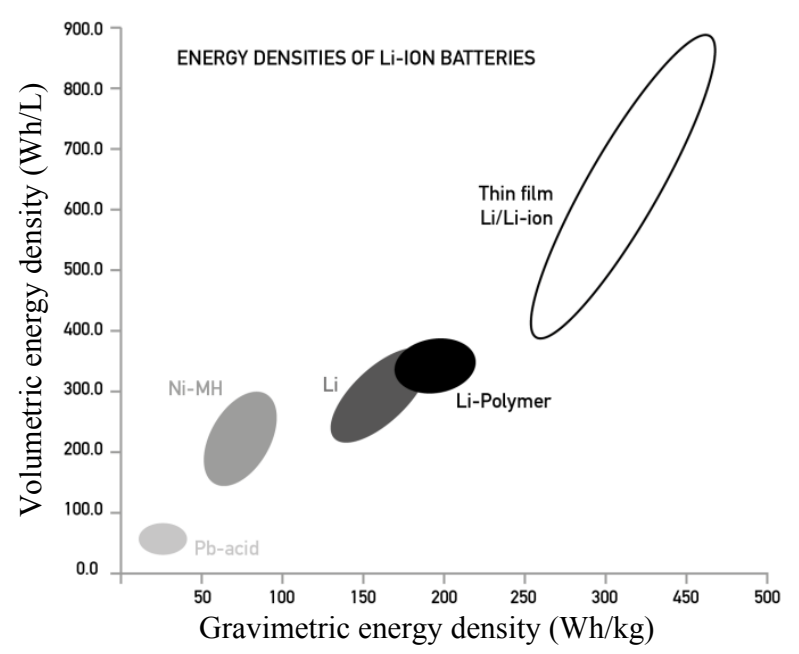

Fig. 1 The gravimetric and volumetric energy densities of selected rechargeable battery systems [17].

Table 4 Design aspects of different battery technologies [17].

\begin{tabular}{lllllll}
\hline Battery type & Shape & Flexible & Safety/environmental & $\begin{array}{l}\text { Operating } \\
\text { temperature } \\
\left({ }^{\circ} \mathrm{C}\right)\end{array}$ & Maintenance & $\begin{array}{l}\text { Specific costs } \\
(\text { Euro/Wh })\end{array}$ \\
\hline $\begin{array}{l}\text { Sulphuric lead-acid } \\
\text { Nickel metal hydride }\end{array}$ & $\begin{array}{l}\text { Cubic } \\
\text { Cylindrical }\end{array}$ & Fluid & $\begin{array}{l}\text { Hazard of shock } \\
\text { Release of gas }\end{array}$ & $-20-60$ & $3-6$ months & 0.50 \\
$\begin{array}{l}\text { Lithium-ion } \\
\begin{array}{l}\text { Lithindrical, prismatic } \\
\text { and pouch cells } \\
\text { dioxide }\end{array}\end{array}$ & Yes & Flammable & $-20-60$ & $60-90$ days & 3.80 \\
\hline
\end{tabular}


components. While transparent electrolytes are known, the lithium-ion battery electrode materials are not transparent and have to be thick enough to store sufficient electrical energy, the traditional approach of using thin films for transparent devices is not suitable. However, if the feature dimension of the battery electrodes is below the resolution of the human eye, the electrodes appears transparent. Yang et al. [19] from Stanford University have reported about novel electrodes, which have this feature by aligning multiple electrodes together, the amount of stored energy increases readily without sacrificing the transparency. This results in a rechargeable battery with an energy density of $10 \mathrm{Wh} / \mathrm{L}$ at a transparency of $60 \%$. The device can also be manufactured on a flexible support, further broadening the potential applications. We may conclude that these features greatly improve applicability of these batteries connected with PV systems in integrated building materials.

\section{Conclusions}

Solar energy is widely under-used and one way to reduce this is to improve production in low-energy places with high demand: large cities. According to this option, larger amounts of electricity consumption in the built environment could be produced by solar PV devices. Accordingly, appropriate solar PV energy conversion devices and energy storage systems are needed. This paper discussed various functional and design qualities that enable an increased diffusion of solar PV and battery storage technology, with a focus on sizing, patterning, shaping of edges, bending and curvature, coloring and transparency. In a comparative analysis of various PV technologies, the criteria taken into account encompassed efficiency of the type of solar cell (PV) and commercial availability. Special attention was paid to the design features of the different PV systems, like flexibility, colour and transparency that might help in utilization of these systems integrated in building material and ornaments in modern architecture. The same procedure was followed for electricity storage devices. By combining the PV and battery technologies that result from these comparisons, we suggest that a combination of silicon-based PV cells and Li-ion batteries could result in a whole new range of PV elements suitable for application in buildings.

\section{References}

[1] M. van Geenhuizen, J. Schoonman, Renewable energy technologies and potentials for adoption, in: M. van Geenhuizen, W.J. Nuttall, B. Gibson, E. Oftedal (Eds.), Energy and Innovation: Structural Change and Policy Implications, Purdue University Press, USA, 2010.

[2] J. Baxter, Z. Bian, G. Chen, D. Danielson, M.S. Dresselhaus, A.G. Fedorov, et al., Nanoscale design to enable the revolution in renewable energy, Energy and Environmental Science 2 (6) 2009 559-588.

[3] B. Badcock, Making Sense of Cities, A Geographical Survey, Arnold, London, 2002.

[4] T. Vogel, Smart Cities - Cities with a Future, The Climate and Energy Fund Promotes Intelligent Urbanity, Climate and Energy Fund, Vienna, 2011.

[5] P. Droege, Urban Energy Transition From Fossil Fuels to Renewable Power, Elsevier, Oxford, 2008.

[6] S. Hammer, Renewable energy policymaking in New York and London: Lessons for other world cities?, in: P. Droege (Ed.), Urban Energy Transition, From Fossil Fuels to Renewable Power, Elsevier, Oxford, 2008, pp. 143-172.

[7] A. Held, M. Ragwitz, R. Haas, On the success of policy strategies for the promotion of electricity from renewable energy sources in the EU, Energy \& Environment 17 (6) (2009) 849-868.

[8] Building Integrated Photovoltaics, WBDG (Whole Building Design Guide), 2011, www.wbdg.org/resources (accessed Feb. 25, 2012).

[9] IEA Technology Roadmap, Solar Photovoltaic Energy, 2012, www.iea.org/about/rewp.htm (accessed Jan. 1, 2013).

[10] K. Neuhoff, Large scale deployment of renewables for electricity generation, Oxford Review of Economic Policy 21 (1) (2006) 88-110.

[11] Solar Utility: Electricity from Sunshine on a Massive Scale in California, Scientific American, Aug. 15, 2008

[12] Greenpeace International, Energy [R] evolution, Reports, 2005, 2008, 2010, 2012, http://www.greenpeace.org /international/en/publications/reports/ (accessed Feb. 25, 
2012).

[13] M.Z. Jacobson, Review of solutions to global warming, air pollution and energy security, Energy Environ. Sci. 2 (2009) 148-173.

[14] M.Z. Jacobson, M.A. Delucchi, Providing all global energy with wind, water and solar power, Part I: Technologies, energy resources, quantities and areas of infrastructure and materials, Energy Policy 39 (2011) 1154-1169.

[15] Sustainable Energy Catalogue for European Decision Makers, European Parliament, SEC (Sustainable Energy Catalogue), 2006.

[16] B. O'Regan, M. Grätzel, A low-cost high efficiency solar cell based on dye sensitized colloidal TiO2 films, Nature 353 (1991) 737-740.

[17] J. Schoonman, Rechargeable batteries for energy storage, in: A.H.M.E. Reinders, J.C. Diehl, H. Brezet (Eds.), The Power of Design, John Wiley and Sons, London, 2012.

[18] D.R. Simon, Characterization of Li4Ti5O12 and LiMn2O4 spinel materials treated with aqueous solutions, Ph.D. Thesis, Delft University of Technology, 2007.

[19] Y. Yang, S. Jeong, L. Hu, H. Wu, S.W. Lee, Y. Cui, Transparent lithium-ion batteries, Proceedings of the National Academy of Sciences of the United States of America (PNAS) 108 (2011) 13013-13018. 